\title{
Gender Influence on School Climate and Organizational Silence Amongst Teachers in Anambra State
}

\author{
Ndidiamaka J. Okeke-James, \\ Innocent C. Igbokwe, PhD \\ Adeline N. Anyanwu, PhD \\ Obiageli, P. Obineme,
}

Nnamdi Azikiwe University, Awka, Anambra State, Nigeria

Doi:10.19044/esj.2020.v16n10p223 URL:http://dx.doi.org/10.19044/esj.2020.v16n10p223

\begin{abstract}
This paper examines the gender influence on school climate and organizational silence among teachers in secondary schools in Anambra State, Nigeria. Correlational research design is used for the study. The population of the study consisted of all the 5498 teachers in 259 secondary schools in Anambra State, comprising 775 male and 4723 female teachers. Two structured questionnaires were adapted as the instruments for data collection. The internal consistency of the instruments was established using Cronbach alpha which yielded 0.81 and 0.91. Four research questions and four hypotheses guided the study. The study reveals that there is no significant relationship between the perception of teachers who teach in an open school climate and their organizational silence. Secondly, there is no significant relationship between the perception of male and female teachers who teach in a closed school climate and their organizational silence. Based on this, recommendations were made.
\end{abstract}

Keywords: School climate, teachers and teachers' organizational silence

\section{Introduction}

School is a vital educational institution where people are groomed into useful living. It is an organized place where people receive formal education that enables an individual to imbibe the acceptable values, skills, behaviour and knowledge of the society. According to Akinnubi (2017) school is a unique community that permits actualization of educational aims, goals and objectives through judicious use of the available human and non-human 
resources. Among the human resources needed to achieve any school objectives are the teachers.

Teachers are the group of people charged with the responsibility of teaching, training, encouraging and inspiring students to learn. In the view of Obikwelu and Nwasor (2017) teachers are those that make strident efforts to improve human cognitive, affective and psychomotor development in the school. In other words, teachers are those that help in academic, social and emotional development of students. To accomplish this, teachers should freely express their observations, views and opinions in the school. This agrees with the intervention of Ofoegbu (2017) that teachers' interactions, views and behaviour play vital role in ensuring the achievement in educational institution.

Unfortunately, a close look at some secondary schools in Anambra State shows that most teachers do not make their opinions known in staff meetings, prefer nonverbal communication or discussing school issues in private, hides personal mistakes or mistake of others, dodge constructive dialogues, restrain providing information about students' behavioural and academic progress or regress. It is this acts that Yamchi, Zahrani and Alvani (2012) called organizational silence. According to them, organizational silence is the behaviour of employees to purposely decide to withhold their opinions and concerns about organizational matters. It is a situation where teachers willingly resolve not to discuss any information concerning their school. Organizational silence is the deliberate choice of the school staff not to express their view or belief about school affair. In the words of Inandi, Gun and Gilic (2017), organizational silence is employees' behaviour of not expressing their opinions when they are faced with a problem in their organizations or they withhold their knowledge and ideas for improvement of their work and organizational purpose. In the context of this study, teachers' organizational silence is defined as a willful teachers' behaviour of resolving to keep information, views and opinions about matters that concern the school. Three types of organizational silence include: acquiescent/accepted silence, defensive/ self-protected silence and pro-social protective silence (Inandia, Gun \& Gilic, 2017). Among these types of organizational silence, none is without consequence.

According to Inandia, Gun and Gilic (2017), acquiescent/accepted silence is a paradox that refers to general acceptance of ideas in a group even when they contradict one's individual ideas. Acquiescent silence is the aspect of organizational silence where employees of organization refrain from expressing information, views and ideas based on the belief that speaking up is pointless and unlikely to make a difference. This type of organizational silence seems to be a reason some teachers prefer nonverbal communication or discussing school issues in private. The consequence of acquiescent silence 
on the part of the principal is that he may ignorantly make mistake because deceitful nature of silent makes him believe his actions are right. On the part of teachers, it may result to lower internal motivation, intra conflict, decrease commitment level and reduce decision making process (Owuor, 2012).

Defensive silence according to Gezer, Katkat, and Mizrak (2016), refers to employee's avoidance of expressing knowledge or thoughts for the fear of encountering a problem as regards to knowledge or idea shared. Defensive silence is a form of silence for self-protection where a teacher does not express his feelings and thoughts because of negative consequence he may face when such personal opinion is expressed. Some teachers seem to exhibit this behaviour in secondary schools today, when a teacher hides personal mistakes or mistake of others as a form of self-protection. The consequence of defensive silence is that it may hinder school objectives as genuine information needed for constructive criticism and evaluation are hindered for self-defense.

Prosocial silence is the silence of one person for the benefit of other employees and the organization. Erenler (2010) noted that this type of silence is different from defensive silence and is characterized with worry for others rather than fear from negative, personal results that may arise when expressing one's ideas. In some secondary schools today, teachers seem to exhibit this behaviour by withholding specific ideas or information with the goal of benefiting other people or the organization. A probable effect of this type of silence is that other education stakeholders may be fed with wrong information on issues concerning the school. Research finding revealed that gender influences organizational silence (Bastug, Yilmaz, Duyan \& Gunel, 2016).

One of the factors that seems to predict teachers' organizational silence is the school climate. School climate is a technical term used to describe the status of human relationships within the operational environment of an educational institution (Nwangwu, 2017). According to Aniagoh (2014), school climate is the quality and characteristics of school life which is based on pattern of students, parents, school personnel's experiences of school life. In other words, school climate is influenced by the knowledge school members gained through activities performed over time in the school. School climate can be defined as the totality of the school members' knowledge acquired over time in school environment through the school structures, policies, practices which influence the interactions and relationship in the school. The main prevailing school climates are open and closed climates.

Open climate is the climate that encourages transparency and free flow of interaction. In the view of Raman, Ling and Khali (2015) healthy climate depicts a school that focuses on academic aspect of the school and the leader is able to influence the teachers to put in their best to enhance students' learning. On the other hand, closed school climate is a climate that shuts doors 
of communication and interaction. In the view of Okorji, Igbokwe and Ezeugbor (2016) a closed climate is a kind of climate that is unhealthy, sick and socially tense. The main characteristic of this type of climate as identified by Igbokwe (2016) to include: non co-operation among the staff, lack of commitment, unsupportive, intolerance and stresses on routine.

In view of the above definitions, teachers' organizational silence seems to have a link to school climate. Teachers exhibiting organizational silence where their primary functions encompass information and knowledge exchange. This situation draws the attention of the researchers to correlate school climate and teachers organizational silence with teachers' gender as intervening variable. Hence, the main purpose of the study is to determine gender influence on school climate and organizational silence amongst teachers in Anambra State. Specifically, this study sought to determine:

1. The relationship between male teachers' perception of open school climate and their organizational silence in secondary schools in Anambra State;

2. The relationship between male teachers' perception of closed school climate and their organizational silence in secondary schools in Anambra State;

3. The relationship between female teachers' perception of open school climate and their organizational silence in secondary schools in Anambra State;

4. The relationship between female teachers' perception of closed school climate and their organizational silence in secondary schools in Anambra State;

The following research questions were formulated to guide the study:

1. What relationship exists between male teachers' perception of open school climate and their organizational silence in secondary schools in Anambra State?

2. What relationship exists between male teachers' perception of closed school climate and their organizational silence in secondary schools in Anambra State?

3. What relationship exists between female teachers' perception of open school climate sand their organizational silence in secondary schools in Anambra State?

4. What relationship exists between female teachers' perception of closed school climate and their organizational silence in secondary schools in Anambra State? 


\section{Hypotheses}

The following null hypotheses were formulated and are tested at 0.05 level of significance.

$\mathrm{H}_{01}$. There is no statistically significant relationship between male teachers' perception of open school climate and their organizational silence.

$\mathrm{H}_{02}$. There is no statistically significant relationship between male teachers' perception of closed school climate and their organizational silence.

$\mathrm{H}_{03}$. There is no significant relationship between female teachers' perception of open school climate and their organizational silence is not significant.

$\mathrm{H}_{04}$. There is no statistically significant relationship between female teachers' perception of closed school climate and their organizational silence.

\section{Methodology}

\section{Research Design}

The correlation survey design was utilized. According to Nworgu (2015) a correlation research design indicates relationship that exists between two or more variables. Thus, the design was deemed as appropriate for this study since it correlated gender influence on school climate and organizational silence among teachers.

\section{Area of the Study}

It was carried out in all the public secondary schools in the six education zones of Anambra State. Anambra state is located in the South- East geopolitical zone of Nigeria. The state was created on $27^{\text {th }}$ August, 1991 out of the Old Anambra State. Its capital is Awka. It has 21 Local Government Areas and 6 education zone. It has inter-state boundaries with Delta State to the West, Imo State and River State to the South, Enugu State to the East and Kogi State to the North.

\section{Sample and Sampling Technique}

The population of the study is composed of all the 5498 teachers in 259 secondary schools in Anambra State. This comprises of 775 male and 4723 female teachers. Using simple random sampling technique $10 \%$ of schools from each education zone was drawn. This comprises of 5 schools out of 48 schools for Aguata zone, 6 schools out of 61 schools for Awka Zone, 5 schools out of 50 schools for Nnewi Zone, 4 schools out of 40 schools for Ogidi Zone, 3 schools out of 32 schools for Onitsha Zone and 3 schools out of 28 schools for Otuocha Zone. This gave rise to 26 sampled schools out of 
259 schools. Using simple random sampling technique ten percent of teachers from each gender were drawn from the schools sampled. This gave a sample size of 550 teachers made up of: 13 males and 55 females for Aguata zone, 16 males and 126 females for Awka zone, 11 males and 69 females for Nnewi zone, 9 males and 72 males for Ogidi zone, 9 males and 120 females for Onitsha zone, 19 males and 31 females for Otuocha zone. This gave the sample size of 550 teachers made up of 77 males and 473 females

\section{Instrument for Data Collection}

The researchers used two adapted structured questionnaires for data collection namely: Organizational Climate Index (OCI) and Teachers' Organizational Silence Questionnaire (TOSQ). The first questionnaire, the Organizational Climate Index (OCI) was developed by Hoy, Smith and Sweetland (2002). OCI was 20 item questionnaires which was used to measure school climate. Each item consists of description of school climate type in the school. Items 1-10 consists of description of open school climate while items 11-20 was on closed school climate.

The second instrument, Teachers' Organizational Silence Questionnaire (TOSQ) was developed by Van Dyne (2003) and was used to collect information on teachers' organizational silence.

Each of the questionnaire consist of two parts each A and B. Part A contained an item on the gender of the teacher while Part B contained 20 items each structured on five-point scale of VHE-Very High Extent-5 points, HEHigh Extent -4 points, ME-Moderate Extent -3 points, LE-Low Extent-2 points and VLE-Very Low Extent-1 point

\section{Validation of the Instrument}

The instruments were subjected to face and content validity by three experts. Two of the experts are in the department of Educational Management and Policy and one in the department of Educational Foundations that houses experts in Measurement and Evaluation. All of them are lecturers in the Faculty of Education, Nnamdi Azikiwe University, Awka.

\section{Reliability of the Instrument}

The internal consistency of the instrument was ascertained using Cronbach Alpha which yielded the indices of 0.81 and 0.91 for the school climate and organizational silence. Thus, the instruments were considered reliable in line with the view of Gliem and Gliem (2003) that the closer Cronbach's Alpha coefficient is to 1.0, the greater the internal consistency of the items in the scale. 


\section{Method of Data Collection}

Data was collected by the researchers with the help of six research assistants. A total of 550 copies of the questionnaires were distributed but 418 copies were considered for analysis, representing $76 \%$ were successfully retrieved.

\section{Method of Data Analysis}

Pearson Product Moment Correlation was considered appropriate for this research. It was used to answer research questions and test hypotheses. Hypotheses were tested at 0.05 level of significance. Accordingly, the calculated probability value $(P)$ was weighted against the stipulated level of significance so that where $P$ value is less than stipulated level of significance (0.05), the null hypothesis was rejected but where the $P$ value is greater than the stipulated level of significance, the null hypothesis was not rejected. In answering the research questions, the following rule suggested by Mukaka (2012) was applied for judging correlation in this work:

\begin{tabular}{|l|l|}
\hline Size of Correlation & Interpretation \\
\hline .90 to $1.00(-.90$ to -1.00$)$ & Very high positive (negative) correlation \\
\hline .70 to $.90(-.70$ to -.90$)$ & High positive (negative) correlation \\
\hline .50 to $.70(-.50$ to -.70$)$ & Moderate positive (negative) correlation \\
\hline .30 to $.50(-.30$ to -.50$)$ & Low positive (negative) correlation \\
\hline .00 to $.30(.00$ to -.30$)$ & Negligible correlation \\
\hline
\end{tabular}

\section{Presentation and Analysis of Data \\ Research Question One}

What is the relationship between male teachers' perception of open school climate and their organizational silence in secondary schools in Anambra State?

Table 1: Pearson's Correlation between male teachers' perception of Open School Climate and their Organizational Silence

\begin{tabular}{lllll}
\hline & $\mathrm{N}$ & Open school climate & $\begin{array}{l}\text { Male teachers' } \\
\text { organizational } \\
\text { silence }\end{array}$ & Remark \\
\hline Open school climate & 73 & 1 & .254 & Negligible \\
$\begin{array}{l}\text { Male teachers' } \\
\text { organizational silence }\end{array}$ & 73 & .254 & 1 & \\
\hline
\end{tabular}

As indicated in table one the relationship between male teachers' perception of open school climate and their organizational silence is .254. This shows a negligible positive correlation between male teachers' perception of open school climate and their organizational silence. 


\section{Research Question Two}

What is the relationship between male teachers' perception of closed school climate and their organizational silence in secondary schools in Anambra State?

Table 2: Pearson's Correlation between male teachers' perception of closed school climate and their organizational silence

\begin{tabular}{llllll}
\hline & $\mathrm{N}$ & $\begin{array}{c}\text { Closed } \\
\text { climate }\end{array}$ & school & $\begin{array}{l}\text { Male teachers' } \\
\text { organizational } \\
\text { silence }\end{array}$ & Remark \\
\hline Closed school climate & 73 & 1 & -.042 & Negligible \\
$\begin{array}{l}\text { Male teachers' } \\
\text { organizational silence }\end{array}$ & 73 & -.042 & 1 & \\
\hline
\end{tabular}

As shown in table two, the relationship between male teachers' perception of closed school climate and their organizational silence was -0.42 . This is an indication that there is negligible negative relationship exist between perception of male teacher on closed school climate and their organizational silence.

\section{Research Question Three}

What is the relationship between female teachers' perception of open school climate and their organizational silence in secondary schools in Anambra State?

Table 3: Pearson's Correlation between Female Teachers' perception of Open School

\begin{tabular}{lllll} 
& \multicolumn{3}{c}{ Climate and their Organizational Silence } \\
\hline & $\mathrm{N}$ & Open school climate & $\begin{array}{l}\text { Female teachers' } \\
\text { organizational } \\
\text { silence }\end{array}$ & Remark \\
\hline $\begin{array}{l}\text { Open school } \\
\text { climate }\end{array}$ & 345 & 1 & .497 & Low \\
$\begin{array}{l}\text { Female } \\
\text { teachers' } \\
\text { organizational } \\
\text { silence }\end{array}$ & 345 & .497 & 1 & \\
\hline
\end{tabular}

As shown in table three, the correlation between female teachers' perception of open school climate and their organizational silence was .497. This shows that there is a low positive relationship exists between female teachers' perception of open climate and their organizational silence. 


\section{Research Question Four}

What is the relationship between female teachers' perception of closed school climate and their organizational silence in secondary schools in Anambra State?

Table 4: Pearson's Correlation between female teachers' closed school climate and their

\begin{tabular}{lccll} 
& $\mathrm{N}$ & $\begin{array}{c}\text { Closed school } \\
\text { climate }\end{array}$ & $\begin{array}{l}\text { Female } \\
\text { teachers' } \\
\text { organizational } \\
\text { silence }\end{array}$ & Remark \\
\hline Closed school climate & 345 & 1 & -.123 & Negligible \\
$\begin{array}{l}\text { Female teachers' } \\
\text { organizational silence }\end{array}$ & 345 & -.123 & 1 & \\
\hline
\end{tabular}

As shown in table four, the correlation between female teachers' perception of closed school climate and their organizational silence was -.123. This shows that negligible negative correlation exists between female teachers' perception of open school climate scores and their organizational silence in secondary schools in Anambra State.

\section{Hypothesis One}

There is no significant relationship between male teachers' perception of open school climate and their organizational silence.

Table 5: Test of Significance of Pearson's Correlation between Male Teachers' Perception of Open School Climate and Their Organizational Silence

\begin{tabular}{llllll}
\hline & $\mathrm{N}$ & $\begin{array}{l}\text { Open } \\
\text { School } \\
\text { climate }\end{array}$ & $\begin{array}{l}\text { Male teachers' } \\
\text { organizational } \\
\text { silence }\end{array}$ & P-value & Remark \\
\hline $\begin{array}{l}\text { Open School } \\
\text { climate }\end{array}$ & 73 & 1 & .254 & 0.479 & $\begin{array}{l}\text { Not } \\
\text { significant }\end{array}$ \\
$\begin{array}{l}\text { Male } \\
\text { teachers' } \\
\text { organizationa } \\
1 \text { silence }\end{array}$ & 73 & .254 & 1 & & \\
\hline
\end{tabular}

As shown in table 5, the correlation between male teachers' perception of open school climate and their organizational silence yields a Pearson's correlation coefficient $(\mathrm{r})=.254$ and $P=0.479$. Since the $P$ is greater than the stipulated level of significance (0.05), the null hypothesis is not rejected ( $P$-value $>$ 0.05). Therefore, there is no significant relationship between open school climate and male teachers' organizational silence. 


\section{Hypothesis Two}

There is no significant relationship between male teachers' perception of closed school climate and their organizational silence.

Table 6: Test of Significance of Pearson's Correlation between Male Teachers' Perception of Closed School climate and Their Organizational Silence

\begin{tabular}{cccccc}
\hline & $\mathrm{N}$ & $\begin{array}{c}\text { Closed } \\
\text { school } \\
\text { climate }\end{array}$ & $\begin{array}{c}\text { Male teachers' } \\
\text { organizational } \\
\text { silence }\end{array}$ & P-value & Remark \\
\hline $\begin{array}{c}\text { Closed school } \\
\text { climate }\end{array}$ & 73 & 1 & -042 & 0.908 & $\begin{array}{c}\text { Not } \\
\text { significant }\end{array}$ \\
$\begin{array}{c}\text { Male teachers' } \\
\text { organizational } \\
\text { silence }\end{array}$ & 73 & -.042 & 1 & & \\
\hline
\end{tabular}

Data analysis in Table 6 revealed that there is no significant correlation between male teachers' perception of closed school climate and their organizational silence, r. $(-.042)=0.908, P-$ value $>0.05$. The null hypothesis is therefore not rejected.

\section{Hypothesis Three}

There is no significant relationship between female teachers' perception of open school climate and their organizational silence.

Table 7: Test of Significance of Pearson's Correlation between Female Teachers' Perception of Open School Climate and Their Organizational Silence

\begin{tabular}{cccccc}
\hline & $\mathrm{N}$ & $\begin{array}{c}\text { Open School } \\
\text { climate }\end{array}$ & $\begin{array}{c}\text { Female teachers' } \\
\text { Organizational } \\
\text { silence }\end{array}$ & P-value & Remark \\
\hline $\begin{array}{c}\text { Open School } \\
\text { climate }\end{array}$ & 345 & 1 & .497 & & \\
$\begin{array}{c}\text { Female } \\
\text { teachers' } \\
\text { organizational } \\
\text { Silence }\end{array}$ & 345 & .497 & 1 & 0.144 & Significant \\
\hline
\end{tabular}

As shown in table 7, the correlation coefficient $\mathrm{r}$ is 0.497 and $P$-value $0.144>$ 0.05 . This shows that there is no significant relationship between female teachers' perception of open school climate and their organizational silence. The null hypothesis was not rejected.

\section{Hypothesis Four}

There is no significant relationship between female teachers' perception of closed school climate and their organizational silence. 
Table 8: Test of Significance of Pearson's Correlation between Female Teachers' Perception of Closed School Climate and Their Organizational Silence

\begin{tabular}{cccccc}
\hline & $\mathrm{N}$ & $\begin{array}{c}\text { Closed school } \\
\text { climate }\end{array}$ & $\begin{array}{c}\text { Female teachers' } \\
\text { organizational } \\
\text { silence }\end{array}$ & P-value & Remark \\
\hline $\begin{array}{c}\text { Closed school } \\
\text { climate }\end{array}$ & 345 & 1 & -.123 & 0.735 & $\begin{array}{c}\text { Not } \\
\text { significant }\end{array}$ \\
$\begin{array}{c}\text { Female } \\
\text { teachers } \\
\text { organization } \\
\text { al silence }\end{array}$ & 345 & -.123 & 1 & & \\
\hline
\end{tabular}

The result on table 8 shows that the Pearson's correlation coefficient $(\mathrm{r})=$ 0.123 and $P=0.735$. Since the $P$ is greater than the stipulated level of significance $(0.05)$, the null hypothesis is not rejected $(P$-value $>0.05)$. Therefore, the relationship between female teachers' perception of closed school climate and their organizational silence is not significant

\section{Discussion of Results}

The result of the analysis revealed that there was a negligible positive relationship between male teachers' perception of open school climate and their organizational silence. Open school climate is a learning atmosphere that supports teacher suggestions and respects the professional competence of the staff. This finding shows in Table 1 that an increase in male teachers' perception of open school climate will lead to increased male teachers' unwillingness to voice their opinion in school matters. This disagrees with Igbokwe (2016) who asserted that open school climate encourages openness and receptive attitude among school members. The probable reason for this disagreement could be because mistrust among school members. This support the views of Gul and Ozcan (2011) in Eriguc, Ozerand Turac (2014), who noted that organizational silence has a link to mistrust between employees and administrators. This is lack of confidence in organizational relationships. This idea points out that in a school where a belief of untrustworthiness exists between staff members and management, people choose to remain silent instead of direct communication even when they perceived school climate to be open. Also teachers perceive that they cannot trust their principal or they can get help when they need it from school members. However, the finding of the first null hypothesis indicates that the relationship between the male teachers' open school climate and their organizational silence is not significant.

In Table 2, the finding of the study also shows that a negligible negative relationship exists between the male teachers' perception of closed school climate and their organizational silence. According to Table 6, this 
relationship is not significant. This shows that closed school climate inversely relates to male teachers' organizational silence and vice versa. In a closed school climate, the principal does not communicate openly with staff members but rather dictates what he or she wants to be done and maintains control over all aspects of the school organization. This finding is in tandem with the opinion of Nwagwu (2017) which stated that closed climate represents the atmosphere that isolates people, frustrates free association and communication. This finding of this study also supports with Igbokwe (2016) who noted that among the characteristics of closed school climate include; non co-operation among staff, lack of commitment, unsupportive and intolerance.

In Table 6, the finding of the second null hypothesis indicates that the relationship between male teachers' closed school climate and their organizational silence is not significant. This shows that closed school climate and teachers' organizational do not relate significantly.

Furthermore, the finding of this study in Table 3 also shows that there is a low positive correlation between female teachers' open school climate and their organizational silence. The relationship shows that a unit increase in female teachers' open school climate scores relates to a unit increase in their organizational silence. The finding of this study disagrees with the opinion of Okorji, Igbokwe and Ezeugbor who asserted that open school climate reflects a school climate where the stakeholders in school- principal and teachers cooperate and support one another. This finding also supports the works of Barkley, Lee and Eadens (2014) who noted that a positive climate exists when teachers, students, parents and administrators function in a manner that is cooperative and beneficial for students' welfare. This finding is not strange to the researcher because the findings of Bastug, Yilmaz, Duyan and Gunel (2016) revealed that organizational silence is more in female employees than their male counterpart. In Table, 7 , the finding of the null hypothesis indicates that the relationship between female teachers' open school climate and their organizational silence is not significant. Put differently, open school climate is a significant factor in predicting female teachers' organizational silence.

Finally, in Table 4, the findings of this study show that there is a negligible negative relationship between female teachers' perception of closed school climate and their organizational silence. This means that closed school climate inversely relate to female teachers' organizational silence. A unit increase in the closed school climate is associated to a unit decrease in level of female teachers' organizational silence. This finding is in line with the opinion of Maniam and Pihie (2017) that closed climate is unhealthy, unfavourable and unfriendly. Closed climate is a learning environment that distort knowledge and information flow. The findings also support Igbokwe (2016) who noted that closed climate is characterized by very high disengagement, high aloofness and low supportiveness among school 
members. This shows that teachers working under closed climate are less concerned about school objectives, lacked effective interaction, communication and interpersonal relationship. In Table 8, the finding indicates that relationship between female teachers' perception of closed school climate and their organizational silence is not significant. This means that closed school climate does not seem to have a significant factor that relates to teachers' organizational silence.

\section{Conclusion}

The study concludes that there is no statistically significant relationship between male teachers' open school climate scores and their organizational silence scores. The correlation coefficient indicated a negligible and positive relationship between male teachers' open school climate scores and their organizational silence scores. There is no significant relationship between the perception of male teachers' closed school climate and their organizational silence scores. The correlation coefficient indicated a negligible and negative relationship.

There is low and positive relationship between female teachers' open school climate and their organizational silence. The relationship between female teachers' open school climate and their organizational silence is not significant. There is negligible and negative relationship between female teachers' closed school climate and their organizational silence. The relationship between female teachers' closed school climate and their organizational silence is not significant.

\section{Recommendations}

The following recommendations have been made based on the findings of the study:

1. The principals should encourage male and female teachers to express their ideas regarding school issues.

2. The principals should involve teachers irrespective of the gender in decision making

3. The principals should be open to constructive criticism coming from the teachers without gender discrimination

\section{References:}

1. Aniagoh, N. (2014). Family and school climate predictors of children's vulnerability to child trafficking in Anambra State.Unpublished Master's degree Thesis. Faculty of Education. University of Nigeria.

2. Akinnubi, O.P. (2017). School facilities maintenance culture. Educational Management.New Perspectives. Lagos:Amfitop books. 
3. Barkley, B., Lee, D \& Eadens, D. (2014). Perceptions of school climate and culture. eJournal of education policy. Retrieved from www.nau.edu

4. Bastug,G. Yitmaz,T. Duyan,M. \& Guel,I.(2016). Organizational silence in sports employees. Journal of Education and Learning, 5(4), 126-132.

5. Erenler, E. (2010). The relationship of employee silence behaviour with some personal and organizational features: A field study on tourism industry. Published doctoral thesis, Hacettepe University, Ankara.

6. Eriguc, G., Ozer, O., \& Turac, I. (2014). Organizational silence among nurses: A study of structural equation modeling. International Journal of Business Humanities and Technology, 4(1), 150-162. Retrieved from http:// www.ijbhtnet.com Jan 2014

7. Gezer, K., Katkat, D., \& Mizrak, O. (2016). Investigation of the correlation between organizational justice and organizational silence of Turkish physical education teachers. International Journal of Sport Studies, 6 (10), 612-619. Retrieved from http:// www.ijssjournal.com

8. Gliem, J. A. \& Gliem R. R. (2003). Calculating, interpreting, and reporting Cronbach's alpha reliability coefficient for Likert-type scales, Retrieved from www.pioneer.netserv.chula.ac.th.

9. Hoy, W. K., Smith, P. A., \&Sweetland, S. R. (2002). The Development of theorganizational climate index for high schools: Its measure and relationship to faculty trust. The High School Journal, 86(2), 38-49.

10. Igbokwe, I. C. (2016). Relationship between School climate ad teachers' job performance in Secondary Schools in Enugu State. (Unpublished Master's thesis), Nnamdi Azikiwe University, Awka, Nigeria.

11. Inandi, Y., Gun, M., \& Gilic, F. (2017). The Study of relationship between women teachers' career barriers and organizational silence: Viewpoint of women and men teachers. Retrieved from www.ejournal.com.DOI: 10.13187/EJCED.2017.3.542

12. Maniam, I., \& Pihie, Z. (2017). The mediating effect of school climate on transformational leadership and school effectiveness. International Journal of Humanities Social Sciences and Education, 4(4), 82-87. doi:10.20431/2349-0381.0404009.

13. Mukaka M. M. (2012). A guide to appropriate use of correlation coefficient in medical research. Malawi Medical Journal, 24(3):69-71

14. Nwangwu, C. (2017). School climate and educational management. Lagos, Amfitop Books. 
15. Nworgu, B. (2015). Educational research: Basic issues and methodology ( $2^{\text {nd }}$ ed.) Enugu:University Trust Publishers.

16. Obikwelu, C., \& Nwasor, V. (2017). Perceived influence of remuneration on teacher motivation in Anambra state secondary schools. Journal of the Nigerian academy of education, 13(1),152-163.

17. Ofoegbu, F. (2017). Educational management new perspective:School personnel management. Lagos, Amfitop Books.

18. Okorji, P., Igbokwe, I. \& Ezeugbor, C. (2016). Relationship between school climate and principals'job performance in secondary schools. European Scientific Journal, 12, 1857-7881. doi:10.19044/esj.2016

19. Owuor, A. (2014). Organizational Silence Affecting the Effectiveness of Organizations in Kenya. Published Master's Thesis. Retrieved from United States Digital Theses database. (Record No. 636736)

20. Raman,A., Ling.C. C., \& Khalid R. (2015). Relationship between school climate and teachers' commitment in an excellent school of Kubang Pasu District, Kedah, Malaysia Mediterranean Journal of Social Sciences, 6(3). doi:10.5901/mjss.2015.v6n3s1p163

21. Van Dyne L., Soon A., \& Botero I. C. (2003). Conceptualizing employee silence and employee voice as multidimensional constructs. Journal of Management Studies 40(6)1359-1392.

22. Yamchi, S., Zahrani, S. \& Alvani, S. (2012). Study on relationship between organizational silence and commitment in Iran.World Applied Sciences Journal 17 (10), 1271-1277. 